\title{
Effects of Graphite Additions on Microstructures and Wear Resistance of Fe-Cr- C-Nb Hardfacing Alloys
}

\author{
Fei HUANG ${ }^{1,2}$, Zhen'an REN ${ }^{1}$, Wumu LIU ${ }^{1 *}$, Hanlin CHEN ${ }^{1}$, Siqiang ZHENG ${ }^{1}$ \\ ${ }^{1}$ Jilin University, School of Materials Science and Engineering, No. 5988 Renmin Street, Changchun, 130022, China \\ ${ }^{2}$ Northeast Electric Power University, Engineering Training Teaching Center, No. 169 Changchun Road, Jilin, 132012, \\ China \\ crossref http://dx.doi.org/10.5755/j01.ms.23.3.16678
}

Received 05 November 2016; accepted 12 February 2017

\begin{abstract}
Hardfacing alloys with different carbon contents by changing graphite additions in flux-cored wires were prepared on a surface of steel C45E4 (ISO 683) using open-arc overlaying. Testing was conducted using scanning electron microscopy (SEM), transmission electron microscopy (TEM), X-ray diffraction (XRD), a Rockwell hardness tester and an abrasion tester to study the effect of variation of graphite additions on the microstructures, hardness and abrasive resistance of the hardfacing alloys. The results show that the microstructures of the hardfacing alloys consisted of ferrite, martensite, retained austenite, independent austenite and $\mathrm{NbC}$ particles. Firstly, as graphite additions increased, the carbon contents gradually increased and the microstructures of the hardfacing alloys changed from ferrite plus $\mathrm{NbC}$ particles to martensite with retained austenite and larger $\mathrm{NbC}$ particles, which was accompanied by hardness increasing and better abrasive resistance. And then the hardfacing layer alloy best performance was obtained as graphite addition was $60 \mathrm{~g}$. The highest hardness was $61.8 \mathrm{HRC}$ and the wear resistance was nearly four times as high as that of the base metal. But excessive graphite additions resulted in some independent austenite present in the microstructures of the hardfacing alloys together with martensite plus retained austenite and $\mathrm{NbC}$ particles, which deteriorated the performance of the hardfacing alloys.
\end{abstract}

Keywords: open-arc overlaying, in-situ synthesis, $\mathrm{NbC}$, graphite, hardfacing alloy.

\section{INTRODUCTION}

In welding and metallurgical processes, $\mathrm{Nb}[1-4], \mathrm{Ti}$ [5-9], B [10], W [11-12] and other alloying elements are prone to form a hard-strengthening phases, leaving the hardfacing alloys with relatively high hardness and good abrasive resistance. Therefore, they are commonly used as additive elements in hardfacing alloys and have been widely used in materials for applications such as agriculture machinery, mining, cement mills and thermal power plants [13-15]. Although its hardness and melting point are both very high, $\mathrm{NbC}$ is not often used due to the small size of its hard-phase particles, which tend to be lost during cutting, reducing the wear-resisting function of the layer [16]. For this reason, most of the existing literature and data suggest that the in-situ synthesized hard phases may combine better with a base interface than with external hard-phase particles, as this can reduce the peeling and wearing rate of the abrasion resistant alloy [17]. Moreover, the carbide microstructure and quantity can affect the wear-resisting property of a material - neither coarse macrostructure nor subcarbide is favorable to the improvement of material abrasive resistance [18]. The abrasive resistance of hardfacing alloys depends on several factors, such as the type, shape and distribution of the hard phases as well as the tenacity and strain-hardening behavior of the base material [19].

Due to the previously listed causes and based on the Fe-C-Cr-Nb hardfacing alloy system, a series of hardfacing

\footnotetext{
* Corresponding author. Tel.: +86-18243086065.

E-mail address: liuwm15@mails.jlu.edu.cn (W. Liu)
}

alloys were prepared on surface of C45E4 steel using an open-arc overlaying method by changing the additive amounts of graphite in self-made flux-cored wires. The differences in microstructure, hardness and abrasive resistance were studied.

\section{MATERIALS AND METHODS}

The materials used were six kinds of self-protective flux-cored wires made for this experiment and the base metal used in this study is steel C45E4, which corresponds to the standard steel grade $\mathrm{C} 45 \mathrm{E} 4$ in international standard ISO 683. The compositions of the hardfacing alloys were adjusted by the additions of powdered graphite. Some high carbon ferro-chrome, ferro-niobium, iron powders as alloying materials and protective aluminum-magnesium alloy and mineral powders were included in flux-cored wires. The dimensions of the test plates were $200 \times 120 \times 10 \mathrm{~mm}$. The carbon content of steel C45E4 is $0.45 \%$ and its microstructures consist of a large amount of grey black pearlite and a smaller amount of white ferrite, which can be seen in Fig. 1.

The experimental hardfacing alloys were prepared on C45E4 steel plates using an NBC-630 inversion welding machine. Graphite additions and the test sample numbers are shown in Table 1 and the overlaying parameters are shown in Table 2. The compositions of the hardfacing alloys were measured by ARL4460 photoelectric direct reading spectrum analyser. The microstructures and phase compositions of each test sample were analyzed using scanning electron microscopy (SEM, EVO18), transmission electron microscopy (TEM, JEM-2100 F), 
energy dispersive X-ray spectrometry (EDS, Link-ISIS) and X-ray diffraction (XRD, D/Max 2500PC, $\lambda \mathrm{CuK} \alpha=0.15418 \mathrm{~nm}, 4 \% \mathrm{~min})$, respectively.

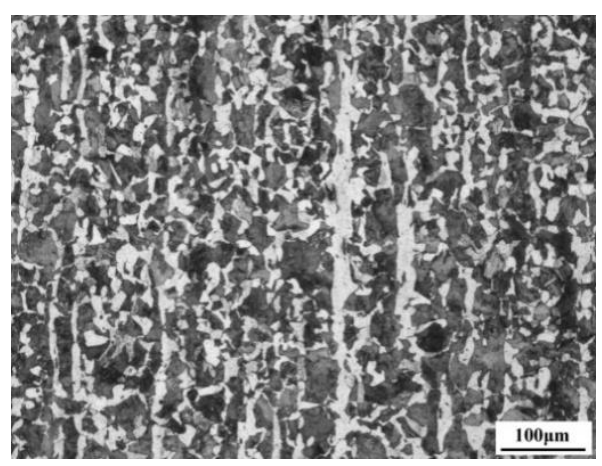

Fig. 1. Microstructure of steel C45E4

The HR-150A Rockwell tester was used to measure the macro-hardness of each test sample. An abrasive wear tester (ML-100) was used to conduct abrasive resistance testing. The abrasion tester was composed of a turning plate that can secure abrasive papers, and a motion-cycled pressure end. During the test, the pressure end moved back and forth while firmly pressing the test sample on the turning plate. The load applied by the pressure end was $9.8 \mathrm{~N}$. The travel distance of the reciprocating motion was $121 \mathrm{~mm}$. The wearing test samples were $6 \mathrm{~mm}$ (outer diameter) $\times 8 \mathrm{~mm}$ (height) cylinders. The abrasive material was No. 600 waterproof SiC abrasive paper. The abrasive resistance of the hardfacing alloys was evaluated based on the mass losses measured using a TE214S type analytical balance.

\section{RESULTS AND DISCUSSION}

\subsection{Phase analysis}

The XRD results on the hardfacing alloys are shown in Fig. 2. The hardfacing alloys consisted of ferrite, martensite, austenite, $\mathrm{NbC}$ and $\mathrm{MC}$ (M representing $\mathrm{Fe}$ and/or $\mathrm{Cr}$ ) phases. In the sample \#1 without graphite addition, only ferrite and/or martensite, $\mathrm{NbC}$ and $\mathrm{MC}$ phases were found The austenite diffraction peaks appeared from sample \#2 and were gradually heightened with the graphite additions increasing. At the same time the diffraction peaks of $\mathrm{NbC}$ and $\mathrm{MC}$ phases were heightened because more and more carbon could promote their synthesis.

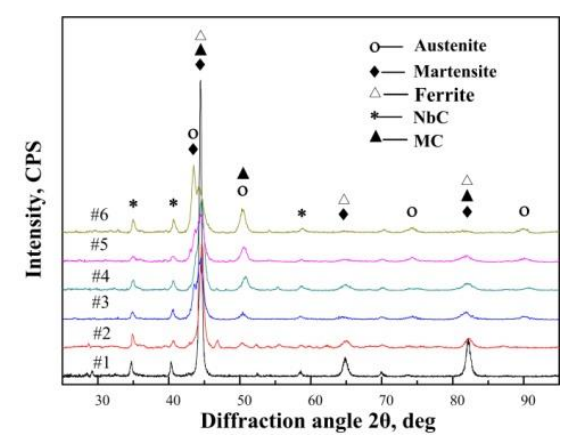

Fig. 2. XRD patterns of hardfacing alloys with various graphite additions

\subsection{Composition and microstructure analysis}

The compositions of the hardfacing alloys are shown in Table 1. With the increase of graphite additions in fluxcored wires, the carbon contents increased from $0.50-1.64 \%$. While about $3 \%$ of chromium and $5 \%$ of niobium were contained in hardfacing alloys.

The main microstructures and phases in different hardfacing alloys can be analyzed and determined by both their morphology in SEM images and compositions in designated spots. Some points (micro-area) analyzed by EDS and corresponding compositions are shown in Fig. 3 and Table 3. In sample \#1 the microstructures composed of grey ferrite matrix, for example point $\mathrm{A}$, and in-situ synthesized $\mathrm{NbC}$ which uniformly distributed in the ferrite matrix with the size around $0.1-1 \mu \mathrm{m}$, for example point $B_{1}$ in Fig. 3 a. Both \#2 and \#3 samples were composed of martensite and retained austenite matrix (point $\mathrm{C}$ ) and larger $\mathrm{NbC}$ particles (point $\mathrm{B}_{2}$ ), which are shown in Fig. $3 \mathrm{c}$ and b. But unlike sample \#1, as the graphite additions increased, the $\mathrm{NbC}$ particles gradually increased in size to about $5 \mu \mathrm{m}$; thereafter the size was nearly unchanged. In sample \#4, microstructures were mainly composed of grey-black martensite and retained austenite with large and more $\mathrm{NbC}$ particles (point $\mathrm{B}_{3}$ ) but some small independent austenite (point $\mathrm{D}_{1}$ ) appeared because of being distinct from the previous compositions. In \#5 and \#6 samples, as the graphite additions continuously increased, more and larger independent austenite (point $\mathrm{D}_{2}$ and $D_{3}$ ) appeared while the mixture of martensite and retained austenite decreased, which are shown in Fig. 3 e and f. However, carbon contents listed in Table 3 should only be taken as a qualitative reference because carbon content measured by EDS is generally much higher than reality as it is a light element.

Table 1. Graphite additions and compositions of the Fe-Cr-C-Nb hardfacing alloys (wt.\%)

\begin{tabular}{|c|c|c|c|c|c|c|c|c|c|c|}
\hline $\begin{array}{c}\text { No. of the wire and } \\
\text { test sample }\end{array}$ & $\begin{array}{c}\text { Graphite } \\
\text { addition, } \mathrm{g}\end{array}$ & $\mathrm{C}$ & $\mathrm{Cr}$ & $\mathrm{Nb}$ & $\mathrm{Si}$ & $\mathrm{Mn}$ & $\mathrm{S}$ & $\mathrm{P}$ & $\mathrm{Al}$ & $\mathrm{Fe}$ \\
\hline$\# 1$ & 0 & 0.50 & 3.17 & 5.38 & 0.56 & 1.50 & 0.008 & 0.027 & 0.012 & $\mathrm{Bal}$ \\
\hline$\# 2$ & 20 & 0.78 & 2.99 & 5.48 & 0.56 & 1.37 & 0.010 & 0.025 & 0.013 & $\mathrm{Bal}$ \\
\hline$\# 3$ & 40 & 1.01 & 2.80 & 5.16 & 0.56 & 1.35 & 0.010 & 0.027 & 0.013 & $\mathrm{Bal}$ \\
\hline$\# 4$ & 60 & 1.35 & 3.01 & 5.74 & 0.62 & 1.46 & 0.010 & 0.027 & 0.014 & $\mathrm{Bal}$ \\
\hline$\# 5$ & 80 & 1.48 & 2.45 & 4.98 & 0.56 & 1.31 & 0.012 & 0.026 & 0.012 & $\mathrm{Bal}$ \\
\hline$\# 6$ & 100 & 1.64 & 2.61 & 4.41 & 0.60 & 1.32 & 0.009 & 0.028 & 0.018 & $\mathrm{Bal}$ \\
\hline
\end{tabular}

Table 2. Overlaying parameters of flux-cored wire

\begin{tabular}{|c|c|c|c|c|c|}
\hline Voltage, $\mathrm{V}$ & Current, $\mathrm{A}$ & Welding speed, $\mathrm{cm} \cdot \mathrm{min}^{-1}$ & Electrode extension, $\mathrm{mm}$ & Interlayer temperature, ${ }^{\circ} \mathrm{C}$ & Post weld state \\
\hline $27.5 \sim 28.5$ & $320 \sim 350$ & 42 & $15 \sim 20$ & 200 & Air-cooling \\
\hline
\end{tabular}




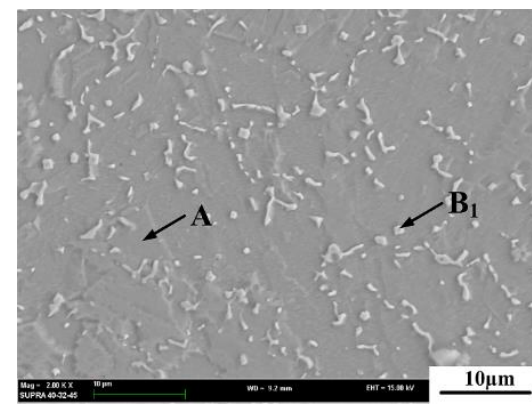

a

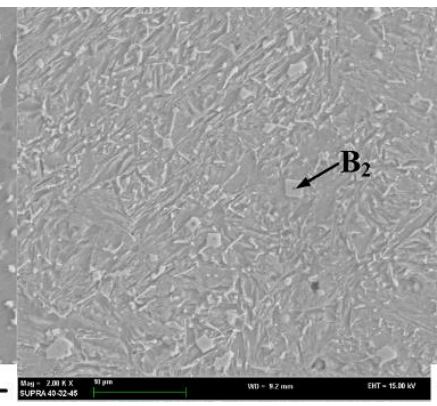

b

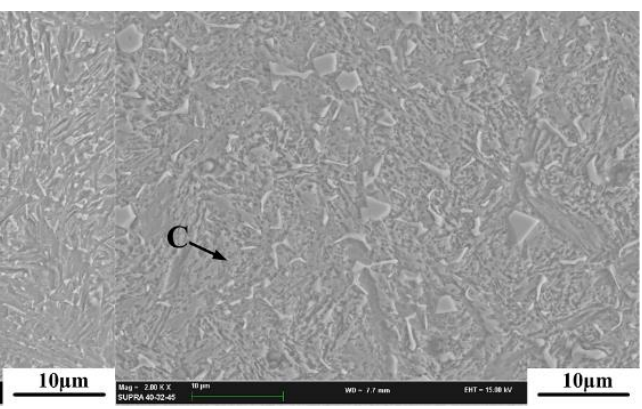

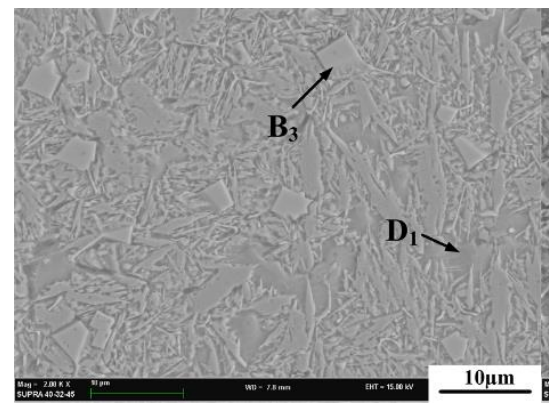

d

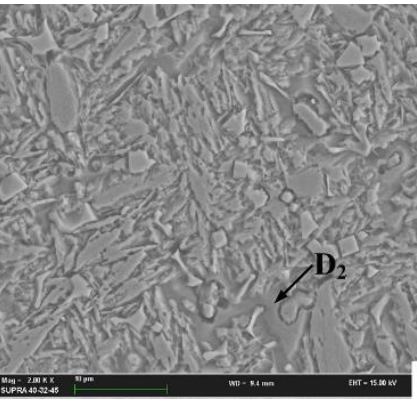

e



$\mathrm{f}$

Fig. 3. SEM feature of the hardfacing alloys: $a$ - ferrite $(A)$ and $N b C$ particle $\left(B_{1}\right)$ in $\# 1$ sample; $b$ - martensite and retained austenite and $\mathrm{NbC}$ particles $\left(\mathrm{B}_{2}\right)$ in \#2 sample; $\mathrm{c}$ - martensite and retained austenite $(C)$ in \#3 sample; $\mathrm{d}$ - martensite and retained austenite, $\mathrm{NbC}\left(\mathrm{B}_{3}\right)$ and independent austenite $\left(\mathrm{D}_{1}\right)$ in $\# 4$ sample; $\mathrm{e}$ - martensite and retained austenite, $\mathrm{NbC}$ and more independent austenite $\left(\mathrm{D}_{2}\right)$ in \#5 sample; $\mathrm{f}$ - less martensite and retained austenite, $\mathrm{NbC}$ and much more independent austenite $\left(\mathrm{D}_{3}\right)$ in \#6 sample

Table 3. EDS composition analysis on some points in Fig. 3 (wt.\%)

\begin{tabular}{|c|c|c|c|c|c|c|c|c|}
\hline \multirow{2}{*}{ Point } & \multicolumn{9}{|c|}{ Chemical composition } & \multirow{2}{*}{ Phase or microstructure } \\
\cline { 2 - 9 } & $\mathrm{C}$ & $\mathrm{Cr}$ & $\mathrm{Nb}$ & $\mathrm{Mn}$ & $\mathrm{Fe}$ & $\mathrm{Ti}$ & $\mathrm{Si}$ & Ferrite \\
\hline $\mathrm{A}$ & 3.67 & 1.72 & 0.32 & 1.39 & 92.42 & - & 0.48 & \multirow{2}{*}{ NbC } \\
\hline $\mathrm{B}_{1}$ & 19.39 & - & 66.21 & - & 8.07 & 3.32 & - & \\
$\mathrm{B}_{2}$ & 18.45 & - & 70.54 & - & 5.22 & 5.79 & - & Martensite and retained austenite \\
$\mathrm{B}_{3}$ & 23.74 & - & 66.18 & - & 3.65 & 6.42 & - & \\
\hline $\mathrm{C}$ & 3.97 & 2.54 & 0.58 & 1.76 & 90.37 & - & 0.77 & Independent austenite \\
\hline $\mathrm{D}_{1}$ & 7.15 & 3.36 & 0.12 & 2.17 & 86.19 & 0.51 & 0.51 & \\
$\mathrm{D}_{2}$ & 7.49 & 5.23 & 0.18 & 2.74 & 83.25 & 0.42 & 0.60 & \\
$\mathrm{D}_{3}$ & 6.98 & 2.36 & 0.26 & 2.27 & 87.17 & 0.38 & 0.57 & \\
\hline
\end{tabular}

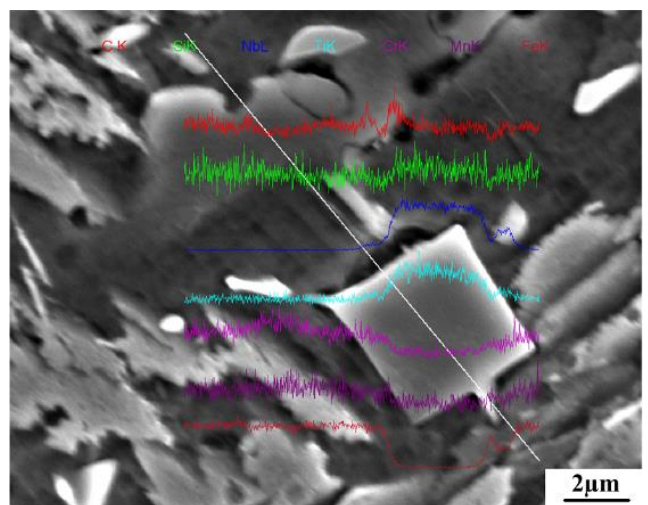

Fig. 4. Analysis result of element line distribution in \# 3 hardfacing alloy by SEM

Fig. 4 shows the element line distribution results of \#3 hardfacing alloy at upper area. The massive phase in the microstructures of the hardfacing alloy was confirmed as $\mathrm{NbC}$ based on the distribution of the elements. Due to the small difference in element contents between the matrix and lamellar structure, energy spectrum analysis was insufficient to determine the phase composition. Therefore, further analysis through TEM was required. Fig. 5 shows the TEM appearance of \# 3 hardfacing alloy and the electron diffraction patterns. Fig. 5 a is calibrated as $\mathrm{NbC}$, which tightly connects with the matrix interface and is formed by in-situ synthesis during overlaying. The matrix with black and light-grey strips in Fig. 5 b is combined by dark martensite and grey retained austenite strips.

\subsection{Performance analysis of the hardfacing alloys}

An abrasive wear test was conducted three times on each of six kinds of hardfacing alloys applied to steel C45E4. The sample masses were measured before and after abrasion test; the average mass losses are shown in Fig. 6. The abrasive wear data of the materials were shown to be inversely proportional to their hardness. The variation trend of wear resistance of the hardfacing alloys was consistent with the variation trend of the hardness, which is similar to the result in the paper of Correa E O [1]. But the hardsurfacing alloys belong to high chromium alloyed cast 
irons in [1] with different microstructures. While in literature [20], the laser cladding coatings consisted of martensite matrix and carbides.



a

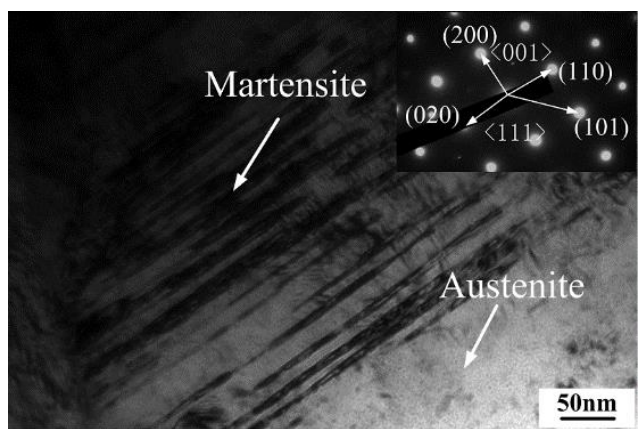

b

Fig. 5. Analysis result of \# 3 hardfacing alloy by TEM: a $-\mathrm{NbC}$ generated by in-situ synthesis; $b$ - martensite and retained austenite

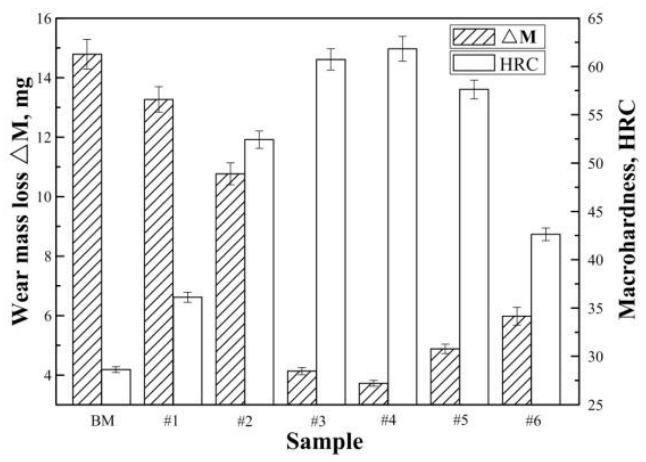

Fig. 6. Hardness and abrasion mass losses of different hardfacing alloys

With $\mathrm{Nb}$ content increasing to $0.71 \mathrm{wt} . \%$, the martensite matrix was refined and more carbide particles appeared, which brought to highest hardness of $620 \mathrm{HV}$ (equal to $56.3 \mathrm{HRC}$ ) and best wear resistance. But more

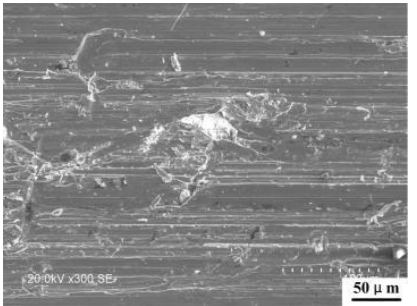

a

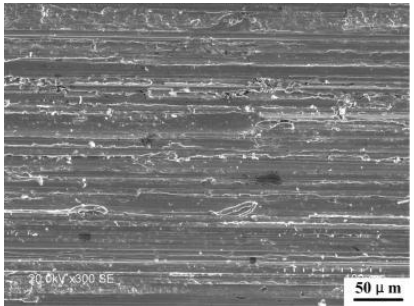

b

$\mathrm{Nb}$ addition resulted in lower performance [20]. In this paper, the same type of alloyed steel hardfacing alloys was prepared with lower $\mathrm{Cr}$ content and higher $\mathrm{C}$ and $\mathrm{Nb}$ contents but similar microstructures. Thus the same changing trends of hardness and wear resistance were gained. However, the highest hardness of $61.8 \mathrm{HRC}$ was achieved because of the higher $\mathrm{C}$ content and larger $\mathrm{NbC}$ particles in the hardfacing alloy \#4.

Average abrasion mass loss of \#1 hardfacing alloy was the largest $(13.27 \mathrm{mg})$ but it is still lower than that of parent metal $(14.79 \mathrm{mg})$. Thus the wear resistance of \#1 was slightly higher than that of the parent metal. The hardness of \#1 hardfacing alloy was $36.1 \mathrm{HRC}$, which was slightly higher than that of parent metal (28.6 HRC). The average abrasion mass loss of \#4 hardfacing alloy was the lowest $(3.72 \mathrm{mg})$ and it had the highest wear resistance, which is nearly four times as high as that of the base metal. The hardness of \# 4 hardfacing alloy was also the highest, at 61.8 HRC. When the additive amount of graphite was higher than $60 \mathrm{~g}$, abrasion mass losses gradually increased, while wear resistance and hardness decreased.

The SEM worn image of the base metal after being abraded is shown in Fig. 7 a. The base metal developed the deepest and widest furrow with large debris, which shows that it was not obstructed in the abrasion process. Fig. $7 \mathrm{~b}$ shows the worn image of \#1 hardfacing alloy with smaller debris because its matrix was strengthened by tiny $\mathrm{NbC}$ particles $(0.1-1 \mu \mathrm{m})$. Fig. $7 \mathrm{c}$ shows the worn image of \#4 hardfacing alloy. Since its microstructure was formed by hard martensite and retained austenite, which was strengthened by large and more NbC particles $(0.5-5 \mu \mathrm{m})$. That developed the smallest and the fewest furrows. With the increase of graphite additions, more and large independent austenite appeared, which resulted in larger and deeper furrows and lower wear-resisting property.

\subsection{The relationship of graphite additions, chemical compositions, microstructures and performance of the hardfacing layers alloys}

With the increase of graphite additions in flux-cored wires, the carbon contents increased and the microstructures and performance of the hardfacing alloys correspondingly changed. For example, the carbon content in \#1 hardfacing alloy was low. Its microstructures mainly consisted of ferrite and $\mathrm{NbC}$ particles, which resulted in low hardness and wear resistance. The increase of carbon contents brought about the in-situ $\mathrm{NbC}$ particles growing up both in number and size and the matrix of hardfacing alloys were composed of martensite and retained austenite.

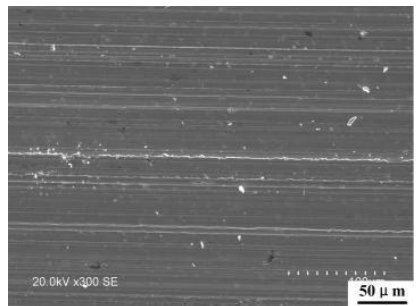

c

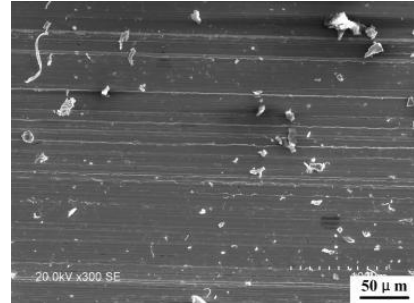

d

Fig. 7. SEM worn images: $\mathrm{a}$ - base metal; $\mathrm{b}-\# 1$ hardfacing alloy; $\mathrm{c}-\# 4$ hardfacing alloy; $\mathrm{d}-\# 6$ hardfacing alloy 
Thus the hardness and wear resistance of the hardfacing alloys increased at the same time. For \#4 hardfacing alloy, the hardness was as high as $61.8 \mathrm{HRC}$ and the abrasive mass loss was reduced to $3.72 \mathrm{mg}$. In other words, its wear resistance was about 3 times higher than that of the base metal. But when the carbon contents continued to increase, the independent austenite in the matrix of the hardfacing alloys was on the increase as well, which led to the hardness and wear resistance reduced correspondingly. According to the data of the hardness and wear resistance, the best graphite addition was $60 \mathrm{~g}$ in the flux-cored wire.

\section{CONCLUSIONS}

1. A series of $\mathrm{Fe}-\mathrm{Cr}-\mathrm{C}-\mathrm{Nb}$ hardfacing alloys were prepared mainly contained martensite, austenite and $\mathrm{NbC}$. As graphite additions increased, the carbon contents increased in hardfacing alloys. More $\mathrm{NbC}$ particles precipitated, which size increased from $0.1-1 \mu \mathrm{m}$ to $0.5-5 \mu \mathrm{m}$. Also, $\mathrm{NbC}$ was tightly connected with the matrix interface formed by in-situ synthesis during overlaying. In the matrix of the hardfacing alloys, martensite and retained austenite first increased and then decreased because more independent austenite was present.

2. Wear resistance of the hardfacing alloys was associated with microstructures and $\mathrm{NbC}$ particle size and followed the variation trend of hardness. When the additive amount of graphite was $60 \mathrm{~g}$, the size of precipitated $\mathrm{NbC}$ was $0.5-5 \mu \mathrm{m}$ and the matrix were mainly composed of martensite and retained austenite. The hardness of the hardfacing alloy was $61.8 \mathrm{HRC}$ and the wear resistance was at its highest value, about 3 times higher than that of the base metal.

3. Excessive graphite additions resulted in some independent austenite present in the microstructures, which deteriorated the performance of the hardfacing alloys. According to the data of the hardness and wear resistance, the best graphite addition was $60 \mathrm{~g}$ in the flux-cored wire

\section{REFERENCES}

1. Correa, E.O., $\quad$ Alcântara, N.G., $\quad$ Valeriano, L.C., Barbedo, N.D., Chaves, R.R. The Effect of Microstructure on Abrasive Wear of a $\mathrm{Fe}-\mathrm{Cr}-\mathrm{C}-\mathrm{Nb}$ Hardfacing Alloy Deposited by the Open Arc Welding Process Surface and Coatings Technology 276 2015: pp. 479-484.

2. Filipovic, M., Kamberovic, Z., Korac, M., Gavrilovski, M. Microstructure and Mechanical Properties of $\mathrm{Fe}-\mathrm{Cr}-\mathrm{C}-\mathrm{Nb}$ White Cast Irons Materials \& Design 47 2013: pp. $41-48$.

3. Zhi, X., Xing, J., Fu, H., Xiao, B. Effect of Niobium on the As-Cast Microstructure of Hypereutectic High Chromium Cast Iron Materials Letters 62 (6-7) 2008: pp. 857-860.

4. Coelho, G.C., Golczewski, J.A., Fischmeister, H.F. Thermodynamic Calculations for Nb-Containing HighSpeed Steels and White-Cast-Iron Alloys Metallurgical and Materials Transactions A 34A (9) 2003: pp. $1749-1758$.

https://doi.org/10.1007/s11661-003-0141-x

5. Liu, H.Y., Yu, F.B., Meng, Q.S., Chen, S.P., Wang, H. Microstructure and Properties of $\mathrm{Fe}-\mathrm{Cr}-\mathrm{C}$ Hardfacing Alloys Reinforced with $\mathrm{TiC}_{-} \mathrm{TiB}_{2} \quad$ Science and Technology of Welding and Joining 17 (5) 2012: pp. 419-423. https://doi.org/10.1179/1362171812Y.0000000028

6. Bedolla-Jacuinde, A., Correa, R., Quezada, J.G., Maldonado, C. Effect of Titanium on the As-Cast Microstructure of a $16 \%$ Chromium White Iron Materials Science and Engineering: A 398 (1-2) 2005: pp. $297-308$.

https://doi.org/10.1016/j.msea.2005.03.072

7. Bedolla-Jacuinde, A., Correa, R., Mejia, I., Quezada, J.G., Rainforth, W.M. The Effect of Titanium on The Wear Behaviour of a $16 \% \mathrm{Cr}$ White Cast Iron under Pure Sliding Wear $263(1-6)$ 2007: pp. 808-820.

8. Wu, X., Xing, J., Fu, H., Zhi, X. Effect of Titanium on the Morphology of Primary $\mathrm{M}_{7} \mathrm{C}_{3}$ Carbides in Hypereutectic High Chromium White Iron Materials Science and Engineering: A $457(1-2)$ 2007: pp.180-185.

9. Zhi, X., Xing, J., Fu, H., Gao, Y. Effect of Titanium on the As-Cast Microstructure of Hypereutectic High Chromium Cast Iron Materials Characterization 59 (9) 2008: pp. $1221-1226$.

10. Tasgin, Y., Kaplan, M., Yaz, M. Investigation of Effects of Boron Additives and Heat Treatment on Carbides and Phase Transition of Highly Alloyed Duplex Cast Iron Materials \& Design 30 (8) 2009: pp. 3174-3179.

11. Guo, J., Liu, S., Zhou, Y., Wang, J., Xing, X., Ren, X., Yang, Q. Stability of Eutectic Carbide in Fe-Cr-Mo-W-V-C Alloy Materials Letters 171 2016: pp. 216-219. https://doi.org/10.1016/j.matlet.2016.02.054

12. Sawamoto, A., Ogi, K., Matsuda, K. Solidification Structures of Fe-C-Cr-(V-Nb-W) Alloys Transactions of the American Foundrymen's Society 94 1986: pp. $403-416$.

13. Buchanan, V.E., McCartney, D.G., Shipway, P.H. A Comparison of the Abrasive Wear Behaviour of IronChromium Based Hardfaced Coatings Deposited by SMAW and Electric Arc Spraying Wear 264 (7-8) 2008: pp. $542-549$.

14. Sapate, S.G., Selokar, A., Garg, N. Experimental Investigation of Hardfaced Martensitic Steel under Slurry Abrasion Conditions Materials \& Design $31(8)$ 2010: pp. $4001-4006$.

15. Kim, J.H., Ko, K.H., Noh, S.D., Kim, G.G., Kim, S.J. The Effect of Boron on the Abrasive Wear Behavior of Austenitic Fe-Based Hardfacing Alloys Wear 267 (9-10) 2009: pp. $1415-1419$.

16. Jankauskas, V., Kreivaitis, R., Milčius, D., Baltušnikas, A. Analysis of Abrasive Wear Performance of Arc Welded Hard Layers Wear $265(11-12)$ 2008: pp. 1626-1632.

17. Just, C., Badisch, E., Wosik, J. Influence of Welding Current on Carbide/Matrix Interface Properties in MMCs Journal of Materials Processing Technology $210(2)$ 2010: pp. $408-414$. https://doi.org/10.1016/j.jmatprotec.2009.10.001

18. Hou, Q.Y., He, Y.Z., Zhang, Q.A., Gao, J.S. Influence of Molybdenum on the Microstructure and Wear Resistance of Nickel-Based Alloy Coating Obtained by Plasma Transferred Arc Process Materials \& Design 28 (6) 2007: pp. $1982-1987$.

19. Buchely, M.F., Gutierrez, J.C., León, L.M., Toro, A. The Effect of Microstructure on Abrasive Wear of Hardfacing Alloys Wear $259(1-6)$ 2005: pp. 52-61.

20. Yang, J., Huang, J., Fan, D., Chen, S. Microstructure and Wear Properties of $\mathrm{Fe}-6 \mathrm{wt} . \% \mathrm{Cr}-0.55 \mathrm{wt} . \% \mathrm{C}-\mathrm{Xwt} . \% \mathrm{Nb}$ Laser Cladding Coating and the Mechanism Analysis Materials \& Design 88 2015: pp. 1031-1041. 